Brit. J. prev. soc. Med. (1975), 29, 249-257

\title{
Regional variations in the development of illness in Finland
}

\author{
ANNA-LIISA HARNI \\ Department of Public Health, University of Oulu, Oulu, Finland
}

\begin{abstract}
Harni, A-L. (1975). British Journal of Preventive and Social Medicine, 29, 249-257. Regional variations in the development of illness in Finland. The aim of the present study is to investigate the incidence of morbidity leading to incapacity for work in the working age population of Finland, and to examine critically the development of such illness and variations between different population groups. An attempt is made to analyse to what extent regional differences in illness development are connected with the communal structure of an area and the provision and use of medical services. The material is based on data from the sickness insurance and national pensions, and mortality statistics. The variables used are those defined by Kalimo $(1967 ; 1968)$ to describe the various features of community structure and the supply of medical services, and data from the insurance and hospital service statistics to measure the use of medical services. The results indicate considerable variation in the course of illnesses between population groups, as expressed as the incidence rates for the various phases of illness or as development probabilities. Illness development proved to be more unfavourable in men than in women. Large regional differences were found, with the course of illnesses appearing to be much more unfavourable in the eastern and northern parts of Finland than in the south and south west. This seems to be closely connected with poorer socioeconomic development and lower urbanization in an area. A clear correlation was found between illness development and the supply and use of medical services in ambulatory care. Illness development was particularly unfavourable in areas where the supply and use of ambulatory medical services, especially doctors' services, were poor. No corresponding correlation was found with the supply and use of hospital services. Development of sickness proved to be connected with a neglect of illnesses at an early phase and delay in seeking medical care. The result is confirmed by variations between population groups in the numbers of sickness benefits awarded. It was confirmed that morbidity resulting in incapacity for work is closely associated with local socioeconomic development.
\end{abstract}

The results of epidemiological studies carried out in Finland during the last 10 years point to considerable regional variations in morbidity as expressed by various objective measures. It was noted that chronic morbidity is distinctly more common in the eastern and northern parts of the country than in the south and west (Purola et al., 1967; 1968; 1971). This project (Harni, 1973) attempts to determine how these large regional differences arise, and examines the regional variations noted in the development of illnesses.
The aim of the study is to examine the incidence of morbidity leading to incapacity for work within different population groups, and to use this as a basis for a critical examination of the development of illness. This will then allow an analysis to be made of how different background factors-such as, the structure of the community, its socioeconomic development, and the provision and use of medical services-are connected with these variations. In addition, an attempt is made to establish indices for the level of health in a community. 


\section{Material AND Methods}

The subjects of the study are all those aged between 16 and 64 years who are living in Finland. Morbidity leading to incapacity for work is examined in population groups defined by age, sex, and district. The material is based on data from the sickness insurance and national pensions statistics on those receiving sickness benefits and disability pensions, together with the relevant mortality statistics. The variables that can influence the development of illness are various features of community structure-such as, urbanization, northerly situation and socioeconomic under-development, expenditure on medical facilities, occupational structure and social expenditure as defined by Kalimo (1967). Other variables are those relating to the supply and use of medical services such as their availability and the distances over which they extend. The medical services examined are physicians, laboratory and nursing services, pharmacies, and hospitals.

The figures obtained at the commune level are adjusted to correspond with the geographical areas studied and weighted according to the size of the working age population. The demand on outpatient services is calculated by the sickness insurance refunds paid out (in Finnish marks per head of population) and the use of hospitals is taken from figures giving the number of hospital admissions, days of hospitalization, and average length of stay.

The population groups for examination are defined according to age and sex in the five sickness insurance administration areas - northern Finland, westein Finland, eastern Finland, south-western Finland, and southern Finland. In the analysis on the influence of the background factors on the development of illness $\mathbf{4 3}$ geographical areas are used, comprising the central hospital districts and sickness insurance districts. These may be divided into rural and urban areas and are shown in the Figure. This analysis involves the calculation of correlation coefficients and the use of progressive regression analysis.

The sickness insurance data used are those for 1968 and the mortality figures those for 1967. Four stages are recognized in the development of an illness, and any case that reached any of these stages during the year in question is recorded. These stages were:

First payment of sickness benefit

Completion of 100 days of sickness benefit

Establishment of permanent disability

Death

Incidence rates are calculated for each of the population groups on the basis of these stages,

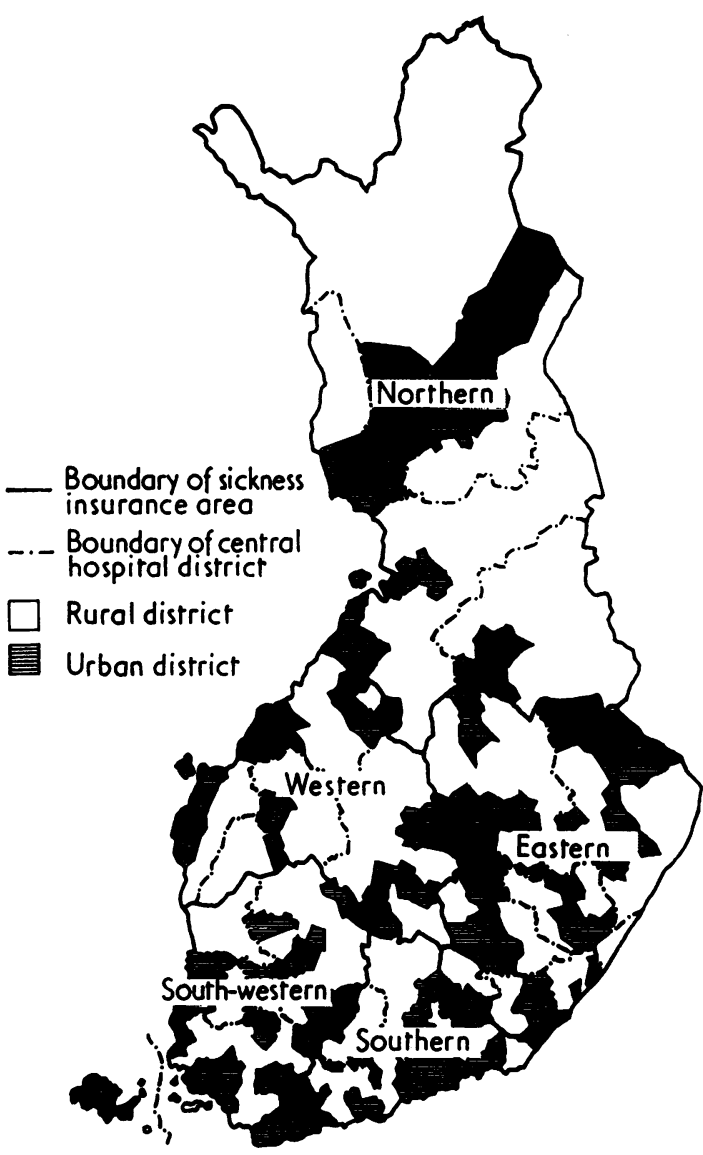

FIGURE Geographical regions of Finland divided into sickness insurance areas and hospital districts-urban and rural.

and by combining the results the following indices for the development of illness are obtained:

$$
\begin{aligned}
& \text { Average duration of sickness benefit } \\
& =\frac{\text { days of benefit }}{\text { new benefits }}
\end{aligned}
$$

Risk of chronicity

$$
=\frac{100 \text {-day benefits }}{\text { new benefits }}
$$

Risk of disability

$$
=\frac{\text { new disability pensions }}{\text { new benefits }}
$$

\section{RESULTS}

Examination based on incidence rates NeW SiCKNess Benefits

Table I presents incidence rates standardized by age for new sickness benefits per 1000 men and 
TABLE I

NUMBER OF NEW BENEFITS AWARDED IN 1968 PER 1000 MEN AND WOMEN OF WORKING AGE (16-64 YEARS) BY SICKNESS INSURANCE AREAS

\begin{tabular}{l|c|c|c|c}
\hline \multirow{2}{*}{ Finland } & \multicolumn{2}{|c|}{ Men } & \multicolumn{2}{c}{ Women } \\
\cline { 2 - 5 } & $\begin{array}{c}\text { Standar- } \\
\text { dized }\end{array}$ & $\begin{array}{c}\text { Unstandar- } \\
\text { dized }\end{array}$ & $\begin{array}{c}\text { Standar- } \\
\text { dized }\end{array}$ & $\begin{array}{c}\text { Unstandar- } \\
\text { dized }\end{array}$ \\
\hline Northern.. & 93.9 & 90.3 & 102.5 & 98.6 \\
Western .. & 95.7 & 96.0 & 97.6 & 97.5 \\
Eastern .. & 86.7 & 86.8 & 103.9 & 103.9 \\
South- & 90.0 & 91.3 & 102.0 & 103.0 \\
western & 90 & 93.5 & 115.2 & 115.5 \\
Southern & 93.2 & & \multicolumn{2}{|c}{106.1} \\
\hline Whole & \multicolumn{2}{|c|}{91.8} & & \\
Finland & \multicolumn{2}{|c|}{9} & &
\end{tabular}

women by sickness insurance areas. The unstandardized rates are also shown. These figures show that the incidence of new sickness benefits was higher among women than men, while only relatively minor geographical fluctuations are found, although there were fewer new benefits paid to men in eastern Finland, and more benefits were paid to women in southern Finland, than those for other areas.

\section{Sickness Benefits of 100 Days AND Disability} Pensions

Table II presents rates for the incidence of sickness benefits of 100 days' duration among men and women of working age, per 1000 . These figures give an indication of regional patterns in the occurrence of chronic illness leading to at least four months' incapacity for work within one year.

Similarly Table III depicts the incidence of new permanent disability pensions per 1000 men and

TABLE II

NUMBER OF BENEFITS OF DURATION 100 DAYS IN 1968 PER 1000 MEN AND WOMEN OF WORKING AGE (16-64 YEARS) BY SICKNESS INSURANCE AREAS

\begin{tabular}{l|c|c|c|c}
\hline \multirow{2}{*}{ Finland } & \multicolumn{2}{|c|}{ Men } & \multicolumn{2}{c}{ Women } \\
\cline { 2 - 5 } & $\begin{array}{c}\text { Standar- } \\
\text { dized }\end{array}$ & $\begin{array}{c}\text { Unstandar- } \\
\text { dized }\end{array}$ & $\begin{array}{c}\text { Standar- } \\
\text { dized }\end{array}$ & $\begin{array}{c}\text { Unstandar- } \\
\text { dized }\end{array}$ \\
\hline Northern . & 16.1 & 14.8 & 12.0 & 10.7 \\
Western .. & 14.3 & 14.5 & 11.6 & 11.6 \\
Eastern .. & 17.5 & 17.7 & 13.4 & 13.7 \\
$\begin{array}{c}\text { South- } \\
\text { western }\end{array}$ & 11.2 & 11.7 & 8.9 & 9.2 \\
Southern.. & 11.4 & 11.3 & 9.2 & 9.2 \\
\hline Whole & \multicolumn{2}{|c|}{13.4} & & \multicolumn{2}{|c}{10.5} \\
Finland & \multicolumn{2}{|c|}{} \\
\hline
\end{tabular}

TABLE III

NUMBER OF NEW PERMANENT DISABILITY PENSIONS AWARDED IN 1968 PER 1000 MEN AND WOMEN OF WORKING AGE (16-64 YEARS) BY SICKNESS INSURANCE ARRAS

\begin{tabular}{l|c|c|c|c}
\hline \multirow{2}{*}{ Finland } & \multicolumn{2}{|c|}{ Men } & \multicolumn{2}{c}{ Women } \\
\cline { 2 - 5 } & $\begin{array}{c}\text { Standar- } \\
\text { dized }\end{array}$ & $\begin{array}{c}\text { Unstandar- } \\
\text { dized }\end{array}$ & $\begin{array}{c}\text { Standar- } \\
\text { dized }\end{array}$ & $\begin{array}{c}\text { Unstandar- } \\
\text { dized }\end{array}$ \\
\hline Northern. . & $11 \cdot 2$ & 9.9 & 7.4 & 6.4 \\
Western .. & 8.1 & 8.6 & 5.4 & 5.4 \\
Eastern .. & $11 \cdot 3$ & 11.6 & 7.0 & 7.4 \\
South- \\
western
\end{tabular}

women of working age during 1968; these therefore indicate regional variations in the degree to which illnesses lead to permanent incapacity. Certain similarities may be noted between the incidence rates presented in Tables II and III, both of which depict the occurrence of unfavourable cases of illness. For instance, such illnesses were more common in men than women, the incidence of 100 day benefits being $28 \%$ higher for men than women, and that of disability pensions $56 \%$ higher. The sharpest differences are noted in the case of the most extreme groups, the women of south-western Finland and the men of eastern Finland, for illnesses developed into chronic cases twice as often in the latter group as in the former, and led to permanent disability three times as often.

\section{MORTALITY}

Table IV shows the mortality rates for men and women in the five sickness insurance areas. Mortality is twice as high in men of working age as in women, although regional differences are smaller than for the other incidence rates considered.

\section{Average Duration of Benefit}

Table $\mathrm{V}$ shows the average duration of sickness benefit for men and women in each of the sickness insurance areas. The average for the whole country in 1968 was 47.9 days. The duration was considerably longer for men than women throughout, the averages for the whole country being 52.9 and 43.8 days, respectively. There are also obvious geographical differences; the average period of sickness benefit for men in eastern and northern Finland was almost one and a half times that in 
TABLE IV

MORTALITY RATE IN 1967 per 1000 MEN AND WOMEN OF WORKING AGE (15-64 YEARS) BY SICKNESS INSURANCE AREAS

\begin{tabular}{l|c|c|c|c}
\hline \multirow{2}{*}{ Finland } & \multicolumn{2}{|c|}{ Men } & \multicolumn{2}{c}{ Women } \\
\cline { 2 - 5 } & $\begin{array}{c}\text { Standar- } \\
\text { dized }\end{array}$ & $\begin{array}{c}\text { Unstandar- } \\
\text { dized }\end{array}$ & $\begin{array}{c}\text { Standar- } \\
\text { dized }\end{array}$ & $\begin{array}{c}\text { Unstandar- } \\
\text { dized }\end{array}$ \\
\hline Northern.. & 7.4 & 6.5 & 3.1 & 2.7 \\
Western .. & 6.8 & 6.9 & 3.1 & 3.1 \\
Eastern .. & 7.5 & 7.7 & 3.1 & 3.2 \\
$\begin{array}{c}\text { South- } \\
\text { western }\end{array}$ & 6.2 & 6.6 & 2.9 & 3.0 \\
$\begin{array}{c}\text { Southern.. } \\
\text { Whole } \\
\text { Finland }\end{array}$ & 6.9 & 6.8 & 3.0 & 3.0 \\
\hline
\end{tabular}

TABLE $V$

AVERAGE DURATION OF SICKNESS BENEFIT PAYMENT IN DAYS FOR MEN AND WOMEN OF WORKING AGE (16-64 YEARS) IN 1968, BY SICKNESS INSURANCE AREAS

\begin{tabular}{|c|c|c|c|c|}
\hline \multirow[b]{2}{*}{ Finland } & \multicolumn{2}{|c|}{ Men } & \multicolumn{2}{|c|}{ Women } \\
\hline & $\begin{array}{c}\text { Standar- } \\
\text { dized }\end{array}$ & $\begin{array}{c}\text { Unstandar- } \\
\text { dized }\end{array}$ & $\begin{array}{l}\text { Standar- } \\
\text { dized }\end{array}$ & $\begin{array}{l}\text { Unstandar- } \\
\text { dized }\end{array}$ \\
\hline Northern. . & $65 \cdot 1$ & $58 \cdot 7$ & $50 \cdot 8$ & $45 \cdot 6$ \\
\hline Western .. & 53.7 & $56 \cdot 4$ & $48 \cdot 4$ & $47 \cdot 5$ \\
\hline Eastern ... & $66 \cdot 2$ & 62.9 & $53 \cdot 1$ & $53 \cdot 1$ \\
\hline $\begin{array}{l}\text { South- } \\
\text { western }\end{array}$ & $41 \cdot 5$ & $45 \cdot 7$ & $37 \cdot 0$ & $39 \cdot 6$ \\
\hline Southern.. & $46 \cdot 4$ & $48 \cdot 5$ & $37 \cdot 2$ & $39 \cdot 9$ \\
\hline $\begin{array}{l}\text { Whole } \\
\text { Finland }\end{array}$ & \multicolumn{2}{|c|}{52.9} & \multicolumn{2}{|c|}{$43 \cdot 8$} \\
\hline
\end{tabular}

south-western and southern Finland. The corresponding geographical variations among the women were less pronounced.

\section{RisK Figures}

Table VI depicts risk figures representing the probabilities of the development of illnesses leading to payment of sickness benefits in the five sickness insurance areas. The probability that an illness will lead to incapacity for work for a minimum of four months, was $14.6 \%$ for men and $9.9 \%$ for women. In other words, the probability that an illness would become chronic, was one and a half times greater in men than in women at the beginning of the benefit period.

The differences in the risk of disability between the sexes were even more marked, being $8.8 \%$ for men over the whole country, and $4.9 \%$ for womenthat is, approximately $80 \%$ higher in men than in women.

There were also considerable geographical differences. The risk of chronic disease was higher by almost $50 \%$ in northern Finland and by almost $60 \%$ in eastern Finland than in southern Finland, and the corresponding variations in the risk of disability were even greater, about 75 to $80 \%$. The three most northerly sickness insurance areasnorthern Finland, western Finland, and easterñ Finland-resembled each other to some extent an proved to be less favourable than south-wester $\mathbb{R}$ Finland and southern Finland, between which n\& great differences in the development of illnesse could be found.

\section{Correlations With Background Variables}

Correlation coefficients between the incidence rates denoting the regional patterns of occurrence of illnesses at the various stages of development, the risk figures, and the principal variables are shown in Table VII. Only those correlations that affect the interpretation of results are presented here. These show that regional patterns of illness development are closely related to background variables. The community structure factors mainly

TABLE VI

RISK FIGURES FOR THE DEVELOPMENT OF ILLNESS IN MEN AND WOMEN, BY SICKNESS INSURANCE AREAS

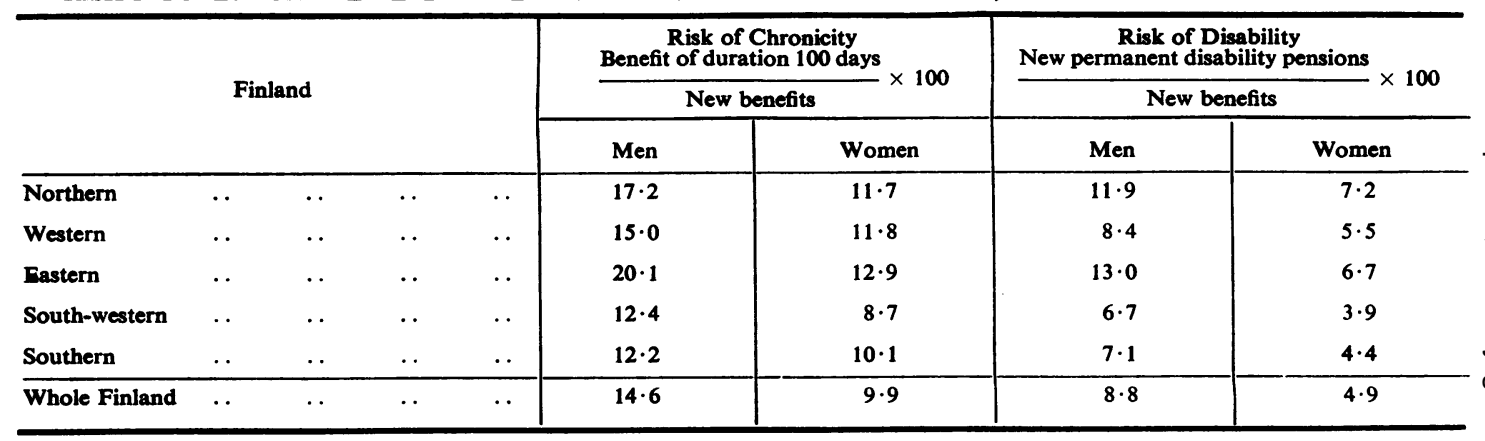


TABLE VII

REGIONAL VARIATIONS IN DEPENDENCE OF DEVELOPMENT OF ILLNESS ON CERTAIN BACKGROUND VARIABLES : COMMUNITY STRUCTURE AND THE AVAILABILITY AND USE OF MEDICAL SERVICES

\begin{tabular}{|c|c|c|c|c|c|c|c|c|}
\hline \multirow{2}{*}{ Incidence Rates } & \multicolumn{2}{|c|}{$\begin{array}{c}\text { Factors of } \\
\text { Community Structure }\end{array}$} & \multicolumn{4}{|c|}{$\begin{array}{l}\text { Availability of } \\
\text { Medical Services }\end{array}$} & \multicolumn{2}{|c|}{$\begin{array}{c}\text { Use of } \\
\text { Medical Services }\end{array}$} \\
\hline & Urbanization & $\begin{array}{l}\text { Northerly } \\
\text { Situation }\end{array}$ & $\begin{array}{c}\text { General } \\
\text { Availability }\end{array}$ & Distance & $\begin{array}{l}\text { Range of } \\
\text { Services }\end{array}$ & $\begin{array}{l}\text { Rel. no. of } \\
\text { Doctors }\end{array}$ & $\begin{array}{l}\text { Doctors' } \\
\text { Services }\end{array}$ & $\begin{array}{c}\text { Hospital } \\
\text { Admissions }\end{array}$ \\
\hline $\begin{array}{l}\text { Morbidity } \\
\text { (new sickness benefits) }\end{array}$ & $-0 \cdot 27$ & -0.00 & $0 \cdot 22$ & $-0 \cdot 18$ & 0.54 & 0.57 & 0.57 & $0 \cdot 25$ \\
\hline $\begin{array}{l}\text { Chronic morbidity } \\
\text { (100-day sickness benefits).. }\end{array}$ & -0.23 & $0 \cdot 64$ & -0.51 & 0.46 & $-0 \cdot 22$ & -0.24 & $-0 \cdot 35$ & 0.40 \\
\hline $\begin{array}{l}\text { Disability } \\
\text { (disability pensions) }\end{array}$ & -0.41 & $0 \cdot 72$ & -0.66 & 0.62 & -0.37 & -0.38 & -0.41 & 0.46 \\
\hline Death .. & -0.43 & $0 \cdot 23$ & -0.33 & $0 \cdot 25$ & $-0 \cdot 16$ & -0.09 & -0.07 & $0 \cdot 33$ \\
\hline
\end{tabular}

Indices of Illness Development

\begin{tabular}{|c|c|c|c|c|c|c|c|c|}
\hline Average duration of benefit & $-0 \cdot 56$ & $0 \cdot 58$ & $-0 \cdot 64$ & 0.63 & -0.48 & -0.51 & $-0 \cdot 53$ & $0 \cdot 28$ \\
\hline Risk of chronicity & $-0 \cdot 38$ & 0.59 & -0.54 & $0 \cdot 51$ & -0.42 & -0.45 & $-0 \cdot 53$ & $0 \cdot 27$ \\
\hline Risk of disability & -0.45 & 0.62 & $-0 \cdot 60$ & $0 \cdot 58$ & -0.46 & -0.49 & $-0 \cdot 50$ & $0 \cdot 39$ \\
\hline
\end{tabular}

Correlations between incidence figures for occurrence of illnesses at certain phases of development, indices of illness development and background variables (correlation coefficients, $N=43$ )

responsible were those associated with urbanization, northerly location, and poor socioeconomic development. The development of illnesses was closely correlated on a regional scale with the availability of medical services, the distance factor proving more significant than the extent of the services, although the number of physicians was of greater importance than the quantitative aspects of the other services as far as regional variations were concerned. Similarly, in the use of medical services the physician was of prime importance. The correlations with the examination and laboratory payments which reflect the use of examination and laboratory services were parallel to those with the repayment of doctors' fees, although no correlation was found between illness development and the use of drugs. In the use of hospital services the number of admissions to general hospitals seemed to be connected most closely with regional variations in illness development.

The number of new benefits awarded appeared to be related to the extent of the medical services available, especially to the number of physicians, so that the number of benefits paid was greater, the greater the number of physicians in the area. There was also a correlation between the number of new benefits and the use of physicians' services, doctors' fees refunded, and the number of hospital days, so that the number of benefits seemed to be more numerous, the more the ambulant care and hospital services were used.
Unfavourable illness development correlated closely with the community structure of the area. Cases involving a long benefit period-that is, 100day benefits and disability pensions, occurred most frequently in northern regions where urbanization was lower and socioeconomic under development more pronounced. There was also a close connexion with the availability of medical services, longer distances being associated with unfavourable development, as was limitation in the range of services. The number of doctors appeared to be the main factor affecting medical services, and unfavourable cases in which the benefit period was long or led to permanent disability, occurred more frequently in areas where there were fewer physicians and less use was made of them. The correlations with the availability of other medical services were much weaker, however, especially in the case of hospital services, for it was found that the number of hospital admissions seemed to be greater, the more numerous the cases of long-term illness.

Mortality rates proved to be highest in those areas where the urbanization features were weakest, although the correlations between mortality rate and availability and utilization of medical services were not so marked.

The results obtained from the different indices of illness development pointed to similar trends, and the connexions between these indices and the background variables were also parallel. The course of those illnesses which led to payment of a sickness 
benefit tended to be more unfavourable in areas where urbanization was weakest and the features of northerly situation and socioeconomic underdevelopment most pronounced. A clear relationship with the availability of medical services was also noted, unfavourable development being more common the poorer the availability and range of medical services in the area, especially in the case of physicians' services, and the longer distances. A very strong correlation pointed to the importance of physicians' services in ambulant care facilities, the course of illnesses being more unfavourable in areas where doctors were used least for ambulant care. Illness development did not, however, seem to depend so closely on the utilization of hospital services.

\section{Regression ANALysis Results}

The purpose of the regression analyses was to ascertain which background variable indices showed strongest covariations with illness development. The degree of covariation is expressed as percentage explanatory power $\left(R^{2} \times 100=\%\right)$. The identified factors may be said to explain the variation observed.

\section{INCIDENCE RATES FOR MORBIDITY AT VARIOUS Phases}

Regression analyses were performed to account for the regional variations in each incidence rate. The explanatory variables were taken to be those presented above-the five community structure factors, the 11 variables denoting the availability of medical services, the four variables for the use of ambulatory care facilities, and the three indicators of the use of general hospital services. The most important of the results of regression analysis follow.

Table VIII depicts the results of a progressive regression analysis performed to explain the regional variations observed in the numbers of new benefits. This incidence rate varies significantly with availability of facilities for medical examination and the amounts refunded to cover cost of treatment. The next best explanatory factor was the number of hospital beds in general hospitals, and after that the overall availability of medical services and the sum refunded for doctors' fees - that is, use of physicians' services. The variables account for $52 \%$, which may be increased to $59 \%$ by including variables representing urbanization and the availability of medical services.

Table IX depicts the results of a progressive regression analysis undertaken to explain regional variations in 100-day benefits, and Table $X$ those of a similar analysis based on new disability pensions. The best explanatory variable proved to be that of northerly situation, and socioeconomic underdevelopment which alone accounted for $42 \%$ of the variation in the former case, and almost $53 \%$ in the latter. The second best variable was that on refunds for the cost of drugs. The variation in the incidence of 100 -day benefits of $65 \%$ can be explained if the factors describing the occupational structure of the community, the level of social and medical care expenses, and certain factors concerned with the availability of outpatient medical services are takem into consideration. The same variables also explairo to some extent the regional differences in the incis dence of disability, as when variations in the use of physicians' services are also considered, these accounted for nearly three-quarters.

The results of a regression analysis regarding regional variations in the mortality rate are shown in Table XI. The main factor is the use of drugs, but the availability of medical services and social expenditure, and some features of community structure, also contribute to a result of almost $75 \%$.

TABLE VIII

REGIONAL VARIATION IN PROPORTION OF NEW BENEFITS BY CERTAIN BACKGROUND VARIABLES IN PROGRESSIVE REGRESSION ANALYSIS

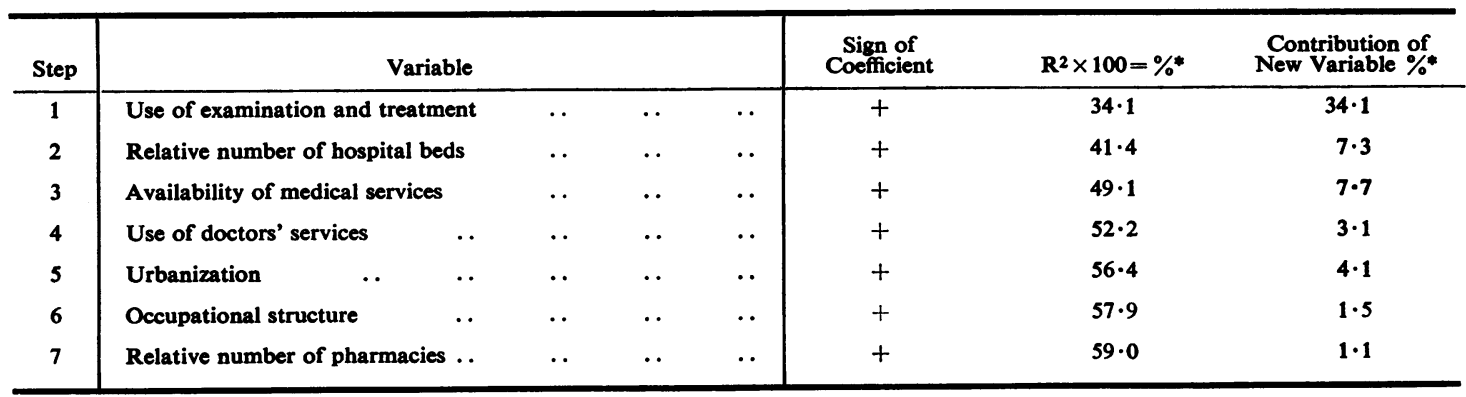

- $\mathbf{R}=$ multiple correlation coefficient

$R^{2} \times 100=$ combined explanation (\%) 
TABLE IX

REGIONAL VARIATION IN PROPORTION OF 100-DAY BENEFITS BY CERTAIN BACKGROUND VARIABLES IN PROGRESSIVE REGRESSION ANALYSIS

\begin{tabular}{|c|c|c|c|c|c|c|c|c|c|}
\hline \multirow{2}{*}{$\frac{\text { Step }}{1}$} & \multicolumn{6}{|c|}{ Variable } & \multirow{2}{*}{$\frac{\begin{array}{c}\text { Sign of } \\
\text { Coefficient }\end{array}}{+}$} & \multirow{2}{*}{$\frac{R^{2} \times 100=\%}{42 \cdot 2}$} & \multirow{2}{*}{$\frac{\begin{array}{c}\text { Contribution of } \\
\text { New Variable \%* }\end{array}}{42 \cdot 2}$} \\
\hline & Northerly situation & . & . & .. & . & . & & & \\
\hline 2 & Use of drugs & $\cdots$ & .. & .. & .. & . & + & $52 \cdot 5$ & $10 \cdot 2$ \\
\hline 3 & Occupational structu & & .. & . & .. & .. & + & $55 \cdot 0$ & $2 \cdot 6$ \\
\hline 4 & Health expenditure & . & .. & .. & .. & .. & - & $58 \cdot 6$ & $3 \cdot 6$ \\
\hline 5 & Social expenditure & .. & .. & .. & $\cdots$ & $\cdots$ & + & $60 \cdot 3$ & $1 \cdot 7$ \\
\hline 6 & Availability of medic & 1 service & & .. & .. & . & - & $61 \cdot 6$ & $1 \cdot 3$ \\
\hline 7 & Distance to nearest $s$ & rgery & . & . & .. & . & + & $63 \cdot 1$ & $1 \cdot 5$ \\
\hline 8 & Distance to medical & cilities & . & . & .. & .. & + & $65 \cdot 2$ & $2 \cdot 1$ \\
\hline
\end{tabular}

* $\mathbf{R}=$ multiple correlation coefficient

$R^{2} \times 100=$ combined explanation $(\%)$

TABLE X

REGIONAL VARIATION IN PROPORTION OF NEW DISABILITY PENSIONS BY CERTAIN BACKGROUND VARIABLES IN PROGRESSIVE REGRESSION ANALYSIS

\begin{tabular}{|c|c|c|c|c|c|c|c|c|c|}
\hline \multirow{2}{*}{$\frac{\text { Step }}{1}$} & \multicolumn{6}{|c|}{ Variable } & \multirow{2}{*}{$\frac{\begin{array}{c}\text { Sign of } \\
\text { Coefficient }\end{array}}{+}$} & \multirow{2}{*}{$\frac{R^{2} \times 100=\%^{*}}{52.9}$} & \multirow{2}{*}{$\begin{array}{c}\begin{array}{c}\text { Contribution of } \\
\text { New Variable \%* }\end{array} \\
52.9\end{array}$} \\
\hline & Northerly situation & .. & . & . & . & . & & & \\
\hline 2 & Use of drugs & .. & .. & .. & .. & . & + & $62 \cdot 4$ & $9 \cdot 5$ \\
\hline 3 & Use of doctors' servi & & .. & . & . & . & - & $65 \cdot 2$ & $2 \cdot 9$ \\
\hline 4 & Social expenditure & . & . & . & . & . & + & $68 \cdot 8$ & $3 \cdot 6$ \\
\hline 5 & Occupational structu & & .. & .. & . & .. & - & $70 \cdot 0$ & $1 \cdot 2$ \\
\hline 6 & Availability of medic & 1 services & . & . & .. & .. & - & $73 \cdot 2$ & $3 \cdot 2$ \\
\hline 7 & Relative number of $\mathrm{s}$ & Irgeries & .. & .. & .. & .. & - & $74 \cdot 3$ & $1 \cdot 1$ \\
\hline
\end{tabular}

* $\mathbf{R}=$ multiple correlation coefficient

$R^{2} \times 100=$ combined explanation $(\%)$

TABLE XI

REGIONAL VARIATION IN MORTALITY RATE BY CERTAIN BACKGROUND VARIABLES IN PROGRESSIVE REGRESSION ANALYSIS

\begin{tabular}{|c|c|c|c|c|c|c|c|c|}
\hline Step & \multicolumn{5}{|c|}{ Variable } & $\begin{array}{l}\text { Sign of } \\
\text { Coefficient }\end{array}$ & $\mathbf{R}^{2} \times 100=\% *$ & $\begin{array}{l}\text { Contribution of } \\
\text { New Variable \%* }\end{array}$ \\
\hline 1 & Use of drugs & $\ldots$ & .. & $\ldots$ & $\ldots$ & + & $26 \cdot 1$ & $26 \cdot 1$ \\
\hline 2 & Availability of medical services & & .. & .. & .. & - & $48 \cdot 5$ & $22 \cdot 4$ \\
\hline 3 & Social expenditure & .. & .. & .. & .. & + & $60 \cdot 5$ & $12 \cdot 0$ \\
\hline 4 & Occupational structure & .. & . & .. & .. & + & $65 \cdot 3$ & $4 \cdot 8$ \\
\hline 5 & Health expenditure & . & .. & .. & . & - & $68 \cdot 5$ & $3 \cdot 3$ \\
\hline 6 & Distance to nearest pharmacy & . & .. & . & .. & + & $72 \cdot 2$ & $3 \cdot 7$ \\
\hline 7 & Relative number of doctors & .. & .. & . & . & - & $74 \cdot 2$ & $2 \cdot 0$ \\
\hline
\end{tabular}

* $\mathrm{R}=$ multiple correlation coefficient

$R^{2} \times 100=$ combined explanation $(\%)$ 
Development of Illnesses Leading to Benefit Payments

Of the results obtained from the regression analyses undertaken to explain the regional variations in the indices-length of the benefit period, risk of chronicity, and risk of disability-only those concerning the risk of disability are presented in Table XII. The regional variations in the average duration of the benefit period were best explained by those in the overall availability of medical services $(41.4 \%)$. When variations in community structure were taken into account about threequarters of the variation could be explained.

The progressive regression analyses presented in Table XII succeed comparatively well in explaining the variations in the risk of disability on the basis of the background variables. The factor of northerly situation and socioeconomic underdevelopment alone accounts for $38 \%$ of the variation, and when other features of community structure are included almost two-thirds of the variation may be explained. When, in addition, differences in the use made of facilities for ambulant care and in the availability of medical services are added, $83 \%$ of the regional variation in the risk of disability is accounted for.

\section{Discussion}

The results suggest that in 1968 the regional variations in the payment of sickness insurance benefits in Finland were related first and foremost to the availability and use of medical services. In the same year, 1968, an interview survey was conducted concerning the whole adult population in Finland. The results of the survey indicated that there were only small differences between the sexes and districts in the number of short-term (9-99 days) periods of illness. These do not suffice to explain the differences in new sickness benefits between the population groups. The criteria for sickness benefits are the same in the whole country. One reason for the differences is to be found in the variations in the use of medical services. This is correlated with the supply of services, their extent and location, and also with sickness behaviour. Women, who have been noted in other connexions to place the greater strain on medical services, received sickness benefits more often than men. The greater number of sickness benefits paid in the urban areas, principally in southern Finland, may be explained as being due to variations in the use of medical services connected with the efficiency of the local health service network while the smaller number paid in the rural and underdeveloped areas, especially in eastern Finland. are associated with a lower use of outpatient medica services because of the shortage of doctors' services longer distances, and lower socioeconomic stano dards. This last reason could be interpreted as indicating neglect of illnesses at an early phase and

TABLE XII

REGIONAL VARIATION IN THE RISK OF DISABILITY BY CERTAIN BACKGROUND VARIABLES IN PROGRESSIVE REGRESSION ANALYSIS

\begin{tabular}{|c|c|c|c|c|c|c|c|c|c|}
\hline \multirow{2}{*}{$\frac{\text { Step }}{1}$} & \multicolumn{6}{|c|}{ Variable } & \multirow{2}{*}{$\frac{\begin{array}{c}\text { Sign of } \\
\text { Coefficient }\end{array}}{+}$} & \multirow{2}{*}{$\frac{\mathbf{R}^{2} \times 100=\%^{*}}{38 \cdot 1}$} & \multirow{2}{*}{$\begin{array}{c}\begin{array}{c}\text { Contribution of } \\
\text { New Variable } \%\end{array} \\
38 \cdot 1\end{array}$} \\
\hline & Northerly situation & .. & . & .. & .. & . & & & \\
\hline 2 & Urbanization & . & .. & .. & .. & .. & - & $46 \cdot 7$ & $8 \cdot 6$ \\
\hline 3 & Health expenditure & .. & .. & .. & .. & .. & - & $52 \cdot 8$ & $6 \cdot 1$ \\
\hline 4 & Social expenditure & . & .. & .. & .. & .. & + & $60 \cdot 1$ & $7 \cdot 3$ \\
\hline 5 & Occupational struct & & .. & .. & .. & .. & - & $63 \cdot 3$ & $3 \cdot 2$ \\
\hline 6 & Use of doctors' serv & & . & .. & .. & .. & - & $66 \cdot 0$ & $2 \cdot 7$ \\
\hline 7 & Relative number of & urgeries & .. & .. & .. & .. & - & $67 \cdot 2$ & $1 \cdot 2$ \\
\hline 8 & Distance to general & ospital & . & .. & .. & .. & + & $68 \cdot 2$ & 0.9 \\
\hline 9 & medica & acilities & . & . & .. & .. & + & $69 \cdot 1$ & $1 \cdot 0$ \\
\hline 10 & nearest & argery & .. & .. & .. & .. & + & $75 \cdot 2$ & $6 \cdot 1$ \\
\hline 11 & nearest & harmacy & . & . & .. & .. & + & $79 \cdot 0$ & $3 \cdot 8$ \\
\hline 12 & Use of drugs & .. & .. & .. & .. & .. & - & $80 \cdot 9$ & $1 \cdot 9$ \\
\hline 13 & Availability of medi & 1 services & & . & .. & .. & - & $82 \cdot 2$ & $1 \cdot 3$ \\
\hline 14 & Distance to nearest & sctor & .. & .. & .. & .. & + & $83 \cdot 1$ & 0.9 \\
\hline
\end{tabular}

* $\mathbf{R}=$ multiple correlation coefficient

$R^{2} \times 100=$ combined explanation (\%) 
delay in seeking medical advice at the onset of illness when the greatest advantage could be obtained from medical care.

The results also indicate considerable variations in the course of illnesses between population groups, as expressed in the incidence rates for the various phases of illness or as development probabilities. The unfavourable course of illnesses in men compared with women was found to be associated with a reluctance to make use of ambulant medical facilities and with delay in seeking medical help. This may also be connected with the different types of illness causing incapacity for work and general differences between the sexes. It is also confirmed that an unfavourable course of illness in an area is normally connected with socioeconomic underdevelopment in that area and with lack of available medical services, principally a shortage of doctors, long distances, and poor use of doctors' services. Similarly it appeared to be associated with a reluctance to consult a doctor, reflected in the low proportion of new sickness benefits. The regional variations in mortality proved to be of much less significance than those in morbidity resulting in incapacity for work, although the same factors were to some extent responsible for these variations.

\section{CoNCLUSIONS}

It is established that marked regional differences in chronic morbidity are due to regional variations in the development of illnesses, which are closely related to local features of community structure and the availability and use of medical services. In addition it was confirmed that morbidity resulting in incapacity for work is closely associated with local socioeconomic development. Morbidity as measured in this manner exhibited a tendency to become concentrated in regions of low socioeconomic development, following the model set up by Myrdal's theory of the concentration of economic resources (Myrdal, 1965), and thus may itself be classed as a negative indicator of regional development. The evaluation procedures employed in this work also enabled new measures of the level of health and the development of illnesses in a population to be elaborated.

Requests for reprints: Dr. Anna-Liisa Harni, Acting Professor, Department of Community Health, University of Kuopio, P.O. Box 138, 70101 Kuopio 10, Finland.

\section{REFERENCES}

HARNI, A- L. (1973). Sairauksien kehityksen alueittainen vaintelu Suomessa. Kansaneläkelaitoksen julkaisuja, Sarja A: 10, 174.

KALIMO, E. (1967). Lääkintäpalvelusten tarjontaorganisaation ekologiset ominaisuudet. Kansaneläkelaitoksen julkaisuja Sarja M: 4, 122.

- (1968). Lääkintäpalvelusten tarjontaorganisaation ekologiset ominaisuudet - II. Kansaneläkelaitoksen julkaisusarji, Sarja M: 8, 19.

MYRDAL, G. (1965). Economic theory and underdeveloped regions, 168. Methuen, London.

Purola, T., Kalimo, E., Sievers, K., and Nyman, K. (1967). Sairastavuus ja lääkintäpalvelusten käyttö Suomessa ennen sairaus vakuutusta. Kansaneläkelaitoksen julkai suja, Sarja A: 1, 399.

,,--- and - (1968). The utilization of the medical services and its relationship to morbidity health resources and social factors. Kansaneläkelaitoksen julkaisuja, Sarja A:3, 243.

- Nyman, K., Kalimo, E., and Sievers, K. (1971) Sairausvakuutus, sairastavuus ja lääkintäpalvelusten käyttö. Kansaneläkelaitoksen julkaisuja, Sarja A: 7, 493. 